\title{
Geological Characteristics and Prospecting Orientation of the Au Polymetallic Ore in Amunik Area of Dulan County, Qinghai Province, China
}

\author{
Ji Shangwen, Xiao Xiaoqiang, Yuan Kequan
}

Qinghai Second Institute of Nonferrous Geological Exploration, 810007, China

Keywords: Dulan county, Amunik, Au polymetallic deposit, Geological characteristics, Prospecting orientation

\begin{abstract}
The Au Polymetallic Deposit in Amunik Area, Dulan County is located in the north margin of the Qaidam Basin. This area is a metallogenic province of the Kunlun (orogenic belt), located in the Saishitengshan Pb-Zn-Au-W-Sn (Cu, Co and Rare earth) metallogenic belt of the $\mathrm{Pb}-\mathrm{Zn}-\mathrm{Mn}-\mathrm{Cr}-\mathrm{Au}-$ whitemica metallogenic belt (III-24) in the northern margin of Qaidam. In this area, the tectonics, magmatic rocks and volcanic rocks are all developed, there are lots of minerals and mineralization leads and rich geological phenomena. In this paper, a discussion was given to the geological characteristics and prospecting orientation of the Au polymetallic deposit in the Amunik area of Dulan County, Qinghai Province, China.
\end{abstract}

\section{Introduction}

Geological and geophysical studies indicate what is exposed is mainly the Upper Devonian fuchsia sandstone, siltstone and slate with intermediate basic lava, and the lower part with limestone lens; the north-westward fault constitutes the main structural framework of this region, and the supporting northeast and northwest faults are developed, which provides conditions for the source, activation, migration and enrichment of mineralization materials; the medium-acid intrusive dikes are widely distributed in this area, and the fissure structure is closely related; the magmatic intrusion is multi-stage and the zoning of each cycle is obvious, which provides abundant material sources and thermal power for mineralization ${ }^{[1]}$. The contact zone between the intrusion and the stratum and the nearby area provide favorable conditions for the formation of hydrothermal and structurally altered rock Au polymetallic deposits.

The tectonic location is in the middle section of the Saishitengshan-Aercituoshan orogenic belt in the Eastern Kunlun Orogenic Belt of the Qinling-Qilian-Kunlun Late Caledonian Orogenic System (as shown in Figure 1). The metallogenic zone belongs to the Little Saishitengshan-Amunikshan lead, zinc, gold, silver and chrom metallogenic sub-zone formed in the Caledonian and Indosinian period, which is a part of the Saishitengshan-Aercituoshan Caledonian Indosinian lead, zinc, gold, tungsten and tin metallogenic belt ${ }^{[2-3]}$.

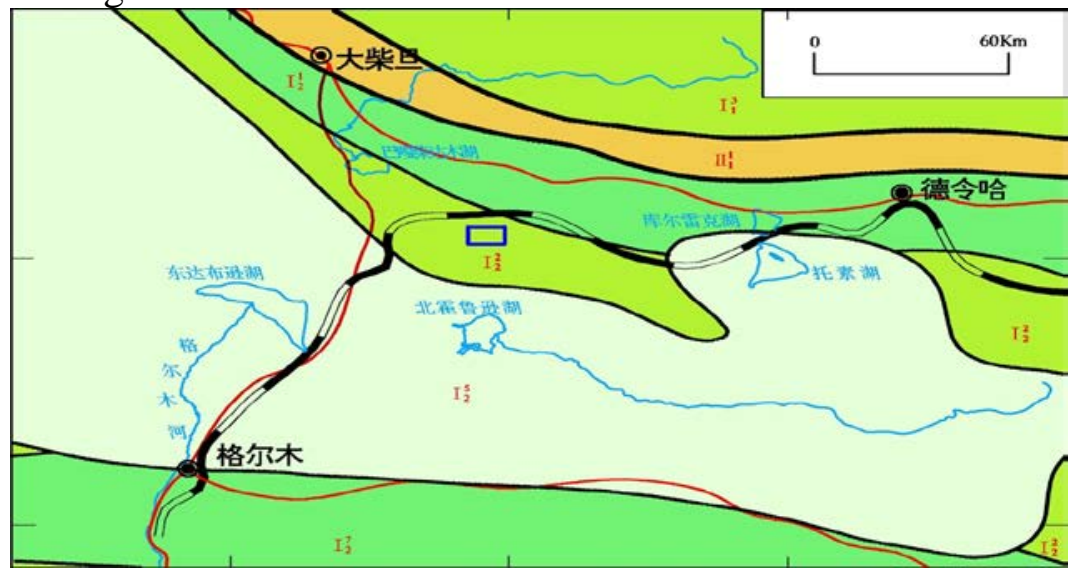

Fig.1 Structure Division of Pre-Checked Area

$\mathrm{I}_{1}^{3}$-South Qilian-Lajishan Orogenic Belt 
$\mathrm{I}_{2}^{2}-$ Saishitengshan-Aercituoshan Orogenic Belt

$I_{2}^{5-}$ Qaidam Late Mesozoic-Cenozoic Fault depressEd Basin

I2-Berkalik-Xiangride Proterozoic Paleocontinent Block

$\mathbb{I}_{1}^{-}-$Z Zongwulongshan Variscan Orogenic Belt

$\Pi_{2}^{1-}$ North Bayan Har Orogenic Belt

In this area, the regional low-temperature dynamic metamorphic rocks are widely distributed, and the metamorphic layers are the Early Paleozoic Tanjianshan Formation and the Late Devonian Maoniushan Formation. Due to the impact of fracture damage, magmatic erosion and Quaternary stratigraphic coverage, band-shaped blocks are formed on the metamorphic strata. The degree of metamorphism is characterized by slate-phyllite grade low green-schist facies, and the original rock features are well preserved.

\section{Geological Characteristics}

\subsection{Stratum}

The main strata exposed in this area are the Devonian Maoniushan Formation, Pliocene Youshashan Formation and Quaternary.

\subsubsection{Devonian Maoniushan Formation (D2-3m)}

The formation is the main stratigraphic unit in the inspection, covering the entire pre-prospected area. The area is in fault contact with the underlying strata between the shoal hills. In the south of the Amunikshan, it is in parallel unconformity contact with the Chengqiangou Formation in the overlying strata, and in the north of the Dadakenwulashan, it is in fault contact with the Amunik Formation in the overlying strata. According to the characteristics of lithology combination, this formation can be divided into 4 lithologic sections in this area, and all sections are integrated contact; 3 lithologic sections are exposed in the pre-prospected area, and they respectively are Section I of Maoniushan Formation $\left(\mathrm{D}_{2-3} \mathrm{~m}^{1}\right)$, Section II of Maoniushan Formation $\left(\mathrm{D}_{2-3} \mathrm{~m}^{2}\right)$, and Sections III of Maoniushan Formation $\left(\mathrm{D}_{2-3} \mathrm{~m}^{3}\right)$.

\subsubsection{Pliocene Youshashan Formation (N2y)}

This formation is mainly sporadically exposed on the south side of the pre-prospected area. Its angle is not integrated on the lower ambush strata, and this area is integrated with the upper strata of the Shizigou Formation.

The lithology is mainly orange-red fine-grained sandstone, light gray-yellow feldspathic quartz sandstone, polymictic conglomerate with gray-green mudstone and light gray-yellow gravel coarse sandstone.

\subsubsection{Holocene Deposits}

Holocene pluvial alluvial sediments (Qhpal): In the Gobi Desert and flat valleys in the mountains and valleys on both sides of the northwest and southwest ends of the pre-prospected area, with small exposed area. The lithology is mainly gravel and sand. The composition of gravel is relatively complex, mainly clastic rocks and volcanic rocks.

Holocene proluvial (Qhpl): It is mainly distributed in the piedmont areas on both sides of the Amunikshan in the pre-prospected area, with few outcrops in this area. At the mouth of each gully, alluvial fans and conical landforms are formed on the landform, and the scale is small. It mainly consists of alluvial mud, sand and gravel, and they are loosely packed.

\subsection{Construction}

The internal fold and fracture structure are the mainly part of the regional structure, and the overall tectonic line direction is northwest-southeast. 


\subsubsection{Fold Structure}

Amunik syncline: Located in the western section of the Amunik syncline in the southern survey area of the pre-prospected area; the strata at the syncline core are the Section II of the Maoniushan Formation $\left(\mathrm{D}_{2-3} \mathrm{~m}^{2}\right)$, and the north wing is the Section I of the Maoniushan Formation $\left(\mathrm{D}_{2-3} \mathrm{~m}^{1}\right)$; the north wing is well exposed, and the south wing is damaged by faults, which is very incomplete and belongs to a broken syncline structure. A series of roughly parallel thrusts and secondary fracture surfaces are developed in the core and wing parts along with the extrusion surface. Most of these fracture surfaces become channels for volcanic eruptions, magmatic intrusion and hydrothermal activity, and they are also favorable locations for the formation of major minerals.

Amunikshan southwest anticline: Located in the southwest corner of the pre-prospected area in the southwest of Amunikshan; the scale is not large, and the western section extends into the adjacent area; the core and the two wing strata are at the Sections III of the Late Devonian Maoniushan Formation $\left(\mathrm{D}_{2-3} \mathrm{~m}^{3}\right)$; the core has developed fault structures and secondary rupture surfaces, and the veins are developed in a goose-like distribution.

\subsubsection{Fracture Structure}

The fault structure is extremely developed, presenting a direction of northwest and north-northwest, mainly northwest. The faults are mainly reverse faults and developed secondary fault structures. The north-west fault controls the distribution of strata and magmatic intrusions.

\subsection{Pulse Rock}

Diabase pulses: they are distributed in the pre-prospected area, and the area is located in the north slope of the Amunikshan. The pulses are stringer-vein-like and lens-like. The exposed width is $2-10 \mathrm{~m}$, the length is tens to hundreds of meters, and the longest is $3 \mathrm{~km}$. Its extension direction is consistent with that of the regional tectonic line, which is mainly northwest-southeast. The pulse tends to be generally south-leaning.

The diabase is dark grayish green, and the rocks present a brilliant green structure and massive structure. They are mainly composed of platy plagioclase, pyroxene and other opaque minerals in the form of granular and granular aggregates.

\section{Characteristics of Ore (Mineralized) Bodies}

Through the anomaly verification carried out in the pre-prospected area, many ore bodies were delineated in the 1:1 soil abnormalities AP1-1 and AP1-9 comprehensive anomalies, including 13 mineralized alteration zones, 2 Au ore bodies, 7 Au mineralized bodies, 1 lead-zinc ore body, and 1 Pb-an mineralized body. Among them, 1 Au ore body (Au2 ore body), 4 Au ore bodies (Au1, Au3, Au4 mineralized body) and $1 \mathrm{~Pb}$-an ore body (PbZn1-1 ore body) had been delineated by predecessors; 13 mineralized alteration zones (Fp1-Fp13), 1 Au ore body (Au9 ore body), 3 Au mineralized bodies ((Au6-Au8 ore body) and 1 Zn ore body (Zn -2 mineralized body) were newly discovered ones.

(1) Characteristics of mineralization alteration zone

A total of 13 mineralized alteration zones were delineated in the pre-prospected area. They were produced in volcanic rocks of Maoniushan, generally 100-480m long and 2-45m wide. The main alterations include limonite mineralization, silicification, sericitization, chloritization and epidotization. Limonite mineralization is in the form of honeycomb and film, and is widely distributed. The silicification is vein-shaped, with a pulse width of $1-6 \mathrm{~m}$, and is gray-white-gray-black, in which star-shaped, sparsely disseminated pyrite mineralization can be seen. The wall rocks of the alteration zones are granite porphyry and black slate, with alteration such as limonite mineralization, silicification, chloritization and epidotization. The occurrence of corrosion-resistant belt is $205-232^{\circ} \angle 58-70^{\circ}$. The main features of mineralized alteration zones are as follows:

Fp1 mineralized alteration zone is about 300m long and 1-6m wide, mainly composed of 
siliceous slate and quartz veins. The rocks are generally fragmented, with network fissures. The surrounding rocks are black slate, and the plate is relatively straight, with a set of developed parallel joints of vertical plate The main mineralization is limonite, and the occurrence is $225^{\circ} \angle 70^{\circ}$.

Fp2 mineralized alteration zone is about $300 \mathrm{~m}$ long and $1-4 \mathrm{~m}$ wide, mainly composed of siliceous slate and quartz veins. The rocks are generally fragmented, with network fissures. The wall rocks are black slate, and the plate is relatively straight, with a set of developed parallel joints of vertical plate .The main mineralization is limonite, and the occurrence is $225^{\circ} \angle 70^{\circ}$. The wall rocks are black slate, and the plate is relatively straight, with a set of developed parallel joints of vertical plate

Fp3 mineralized alteration zone is about $410 \mathrm{~m}$ long and $1-4 \mathrm{~m}$ wide, mainly composed of siliceous slate and quartz veins. The rocks are generally fragmented, with network fissures. The surrounding rocks are black slate, and the plate is relatively straight, with a set of developed parallel joints of vertical plate The main mineralization is limonite, and the occurrence is $216-225^{\circ} \angle$ $67-70^{\circ}$.

Fp12 mineralized alteration zone is about 390m long and $25-45 \mathrm{~m}$ wide, mainly composed of granite porphyry and quartz veins. The rocks are generally fragmented, with network fissures. The surrounding rocks are granite porphyry.

Fp13 mineralized alteration zone is about $380 \mathrm{~m}$ long and $25-30 \mathrm{~m}$ wide, mainly composed of granite porphyry and quartz veins. The rocks are generally fragmented, with network fissures. The surrounding rocks are granite porphyry.

(2) Characteristics of ore (mineralized) bodies

A total of $2 \mathrm{Au}$ ore bodies (Au2, Au9 ore bodies), 7 Au mineralized bodies (Au1, Au3, Au4, Au5, Au6, Au7, Au8 mineralized bodies), $1 \mathrm{~Pb}-\mathrm{Zn}$ ore body (1 PbZn1 ore body) and $1 \mathrm{Zn}$ mineralized body (Zn2 mineralized body) were circled in the pre-prospected area. They are exposed in the volcanic rock slate at the Sections III of Maoniushan Formation $\left(\mathrm{D}_{2-3} \mathrm{~m}^{3}\right)$. The lithology is grayish-white dacite tuff, rhyolite, dacite slate, shale, etc. The intrusive rocks are mainly diorite. There are many silicified and limonite altered zones in the slate; silicification is filled with fine quartz veins along dense joints; the surface of quartz veins is mostly limonite mineralized, and no primary pyrite is seen; however, the surface of quartz veins has relatively dense residual holes, which may be the residual crystal hole of pyrite ${ }^{[4-5]}$. The characteristics of these ore bodies are listed below.

Au2 ore body: This ore body is northwest-southeast and lenticular, and controlled by a single project; the surface trace length is about $240 \mathrm{~m}$, and the thickness is $1.84 \mathrm{~m}$; the occurrence is $217^{\circ} \angle$ $63^{\circ}$. Au grade is $2.21-3.35 \mathrm{~g} / \mathrm{t}$. Ore-bearing rocks are silicified and limonite slates, and the rocks are generally broken, with network fissures. The wall rocks are black slate, and the plate is relatively straight, with a set of developed parallel joints of vertical plate

Au9 ore body: This ore body is a northwest-southeast and lenticular, controlled by surface grooves; the length of the surface trace is about $330 \mathrm{~m}$ and the average thickness is $2.25 \mathrm{~m}$; the occurrence is $228^{\circ} \angle 72^{\circ}$. The Au grade is $0.14-2.43 \mathrm{~g} / \mathrm{t}$, with average grade $1.27 \mathrm{~g} / \mathrm{t}$. It was produced in the F13 alteration zone.

Au1 mineralized body: this mineralized body is northwest-southeast and lenticular, with a tailing-out-regeneration phenomenon locally. It controlled by a single project. The surface exposed length is about $150 \mathrm{~m}$ and the thickness is $0.72 \mathrm{~m}$. The Au grade is $0.76 \mathrm{~g} / \mathrm{t}$. The ore body is produced in siliconized and limonite slate.

Au3 mineralized body: this mineralized body is northwest-southeast and lenticular, with a tailing-out-regeneration phenomenon locally. Controlled by a single project, the surface exposed length is about $100 \mathrm{~m}$ and the thickness is $0.72 \mathrm{~m}$. The Au grade is $0.21 \mathrm{~g} / \mathrm{t}$. The ore body is produced in the quartz vein of limonite ore.

Au4 mineralized body: This mineralized body is northwest-southeast, and produced in the quartz vein in the shape of lens. It is controlled by a single project and is about $100 \mathrm{~m}$ in length, $0.5 \mathrm{~m}$ in thickness, and Au grade is $0.18 \mathrm{~g} / \mathrm{t}$.

Au5 mineralized body: This mineralized body is northwest-southeast, and produced in the quartz 
vein in the shape of lens. It is controlled by a single project and is about $100 \mathrm{~m}$ in length, $0.5 \mathrm{~m}$ in thickness, and Au grade is $0.13 \mathrm{~g} / \mathrm{t}$.

Au7 mineralized body: This mineralized body is northwest-southeast and lenticular, and controlled by a single project; the surface trace length is about $100 \mathrm{~m}$, and the thickness is $1.2 \mathrm{~m}$; the occurrence is $218^{\circ} \angle 73^{\circ}$, and $\mathrm{Au}$ grade is $0.16 \mathrm{~g} / \mathrm{t}$. Ore-bearing rocks are silicified and limonite quartz veins. The rocks are generally broken, with network fissures. Wall rocks are black slate, and the plate is relatively straight, with a set of developed parallel joints of vertical plate

The PbZn1 ore body is produced in tectonic belts in tuff. It is $320 \mathrm{~m}$ long and $5.61 \mathrm{~m}$ thick. The $\mathrm{Pb}$ grade is $0.12 \sim 0.79 \%$ and $\mathrm{Zn}$ grade is $0.28 \sim 10.6 \%$, with an average value of $3.66 \%$.

The Zn2 mineralized body is produced in tuff with a length of $120 \mathrm{~m}$, a thickness of $7.2 \mathrm{~m}$, and the $\mathrm{Zn}$ grade is $0.28-0.35 \%$.

\section{Prospecting Signs}

The pre-prospected area is structural ore-control. The tectonic alteration zone with strong silicification and limonite mineralization in the volcanic rocks of the Maoniushan Formation controls the output location of the ore body ${ }^{[6-7]}$. Through the analysis of relevant data and preliminary geochemical anomalies, the prospecting signs in the area have been initially determined, as shown below:

Strata: mainly in the volcanic rocks of the Maoniushan Formation, and the ore-forming lithology are siliceous slate, rhyolite porphyry, and dacite tuff.

Tectonics: northwest-ward altered fracture zone is the ore-controlling structure in this area.

Alteration of wall rocks: tectonic alteration belts with limonite mineralization and silicification, and especially those with strong silicification are relatively enriched in mineralization.

Geophysical and geochemical anomalies: The area with abnormally high value of AuAgPbZn combination in geochemical exploration and the area with altered zone are important prospecting indicators.

In summary, ore (mineralized) bodies are produced in the tectonic alteration zone, and the silicification and limonite mineralization are strong. Due to the influence of the fault structure, they are locally enriched in ore deposits. It is preliminarily believed that the metallogenic type is a tectonic alteration type of Au polymetallic deposit.

\section{Conclusion}

In summary, this area has a good geological background of mineralization. There are good geochemical anomalies there, and the geochemical anomalies of all measuring scales tally well. In addition, the anomalies coincide with the geological background of known structures, ore (mineralized) bodies found. Through comprehensive analysis of the data, it was found that it is necessary to carry out further geological and geophysical studies due to the insufficient inspection and verification of geochemical anomalies in the past.

\section{References}

[1] Sun Jiaopeng, Chen Shiyue, Peng Yuan, et al. Research on Northern Qaidam Tectonic Attributes during Devonian [J]. Journal of China University of Petroleum (Natural Science Edition), 2015(02): 23-30

[2] Zhang Kexin, Pan Guitang, He Weihong, et al. New Division of Tectonic-Strata Superregion in China [J]. Earth Science (Journal of China University of Geosciences), 2015(02): 206-233

[3] Wang Yang, Dai Zuowen and Li Jianbing. On the Geological and Geochemical Characteristics of Wudashan Lead-Zinc Deposit in Dadaken, Qinghai Province [J]. Acta Mineralogica Sinica, 2015 (S1): 624

[4] Li Jinchao, Du Wei, Kong Huilei, et al. Division of Metallogenic Units in East Kunlun and Its 
Adjacent Area [J]. Global Geology, 2015(03): 664-674

[5] Ma Guodong, Li Yulian, Li Haibin, et al. Geological Characteristics and Genetic Analysis of $\mathrm{Pb}-\mathrm{Zn}$ Polymetallic Deposits in Shaliuhe District, Dulan County, Qinghai Province [J]. Mineral Resources and Geology, 2014(05): 560-567

[6] Xia Wenjing, Niu Manlan, Yan Zhen, et al. Sedimentary Facies Assemblage Characteristics of the Maoniushan Formation in the Maoniushan area on Northern Margin of the Qaidam Terrane [J]. Acta Geologica Sinica, 2014(05):943-955

[7] Deng Jian. The Metallogenic Conditions and Prospect Evaluation of the Pb-Zn Polymetallic in Qinghai Amunic [D]. Chengdu University of Technology, 2016.85 